\title{
Evaluation for the effects of different cleaning techniques applied on Küfeki Stones Used in historical buildings in İstanbul
}

\section{İstanbul'daki tarihi yapılarda kullanılan Küfeki Taşları üzerinde uygulanan farklı temizleme yöntemlerinin etkilerinin değerlendirilmesi}

\author{
Tuğce ERÖZEMEN ${ }^{1}$ (D), Ömer ÜNDÜL $L^{2 *}$ iD,$N a m ı k A Y S A L^{3}$ (D) \\ ${ }^{1}$ Institute of Graduate Studies, Istanbul University, Istanbul, Turkey. \\ tugcerozmen@gmail.com \\ 2,3Department of Geological Engineering, Faculty of Engineering, Istanbul University, Istanbul, Turkey. \\ oundul@istanbul.edu.tr, aysal@istanbul.edu.tr
}

\begin{abstract}
Istanbul hosts large amount of historical buildings. Many of these buildings are made of limestone, fossiliferous limestone and clayey limestone widely known in the region as "Küfeki Stones". In this study the effect of varying cleaning techniques on altered Küfeki stones was investigated. Within this respect, fresh Küfeki stone samples from original building stone (Bakırköy Küfekisi) and recently used substitute rocks from different quarries and regions around Istanbul were compiled. Mineralogical, petrographic and chemical analysis followed by physical and mechanical properties were investigated for these stones. Same stone samples were subjected to accelerated deterioration mechanisms. These altered stones were then cleaned with laser cleaning and pressurized micro-sand blasting techniques and weight losses were calculated and visual changes were determined. The results revealed that rock micro-texture and physical properties should be considered in determining the appropriate cleaning technique. Besides, the usage type of the stone and type of deterioration mechanism should also be considered during the determination of cleaning technique. It is also emphasized that the laser cleaning is less destructive method for cleaning Küfeki stones among the investigated techniques.
\end{abstract}

Keywords: Deterioration, İstanbul, Küfeki stone, Cleaning methods.
Öz

İstanbul'daki pekçok tarihi yapıda, çoğunlukla kireçtaşı, fosilli kireçtaşı ve killi kireçtașlarını bünyesinde barındıran ve bölgede "Küfeki tașı" olarak adlandırılan taşlar kullanılmıştır. Bu çalışma kapsamında, bozunan Küfeki taşlarının üzerinde farklı temizleme yöntemleri denenmiș ve taș üzerindeki etkileri araștırılmıștır. Bu kapsamda, Küfeki taşı olarak kullanılan orijinal yapıtaşlarından (Bakırköy Küfekisi) ve günümüzde bu tașların yerine kullanılan farklı ocak sahalarından taze örnekler alınmıştır. Bu örnekler üzerinde mineralojik, petrografik, kimyasal analizler ile fiziksel ve mekanik deneyler gerçekleștirilmiștir. Ardından aynı örnek gruplarının farkll, hızlandırılmış eskitme yöntemleri ile bozunmaları sağlanmıştır. Eskitilen örnekler lazer ve basınçl mikro kumlama yöntemleri ile temizlenmis ve temizlenen taşların kütlece ağırlık değişimleri ile görsel değişimleri ayrıntılı olarak belirlenmiștir. Elde edilen bulgulara göre, temizleme yöntemlerinin seçiminde mutlaka kayaç içyapısı ve fiziksel özelliklerinin gözetilmesi gerekliliği bir kez daha önemini göstermiștir. Bunun yanında tașın kullanım şeklinin ve kirletici türünün de yine temizleme yönteminin seçimi açısından dikkate alınması gerektiği ortaya konmuștur. Küfeki tașları özelinde ise lazer ile temizleme yönteminin fiziksel olarak taşa daha az hasar veren yöntem olduğu belirlenmiștir.

Anahtar kelimeler: Bozunma, İstanbul, Küfeki taşı, Temizleme yöntemleri.

techniques used to remove the patina from the rock, harms the rocks surface and effects on the service life of the stone. Therefore, the less harmful cleaning techniques should be investigated and operated.

Paper describes the mineralogical, petrographic, physical and mechanical properties of the Küfeki stones obtained from different quarries (Bakırköy, Sazlıbosna and Pınarhisar) which are close to the city and used as original (Bakırköy Küfeki stone) or alternative (Sazlıbosna and Pınarhisar) building stones in many historical buildings. In the second part of the study, Küfeki Stones were artificially aged then they were cleaned with different cleaning techniques. After cleaning process weight losses and visual changes of investigated stones were determined to evaluate the efficiencies for different cleaning techniques.

\footnotetext{
${ }^{*}$ Corresponding author/Yazışılan Yazar
} 
The methods and findings of this research identify the effects of various cleaning techniques on artificially aged Küfeki stones in such a detail for the first time in scientific literature.

\section{Sampling and methodology}

Bakırköy region was the major quarry site for Küfeki stone during periods of Rome, Byzantium and Ottoman Empires. Nowadays, due to the increase in population and widening of settlement areas these ancient quarries have not been be operated since a long time [8]. For these reasons, Sazlıbosna limestone quarry becomes the most active quarry site due to its close location and rock quality which is suitable for extracting big size blocks. Some other quarry sites stand in the western part of İstanbul which are between Vize (Kırklareli) and Saray (Tekirdağ). Within this respect, block samples with dimensions of $15 \times 20 \times 40 \mathrm{~cm}$ were gathered from different quarries as given in Figure 1.

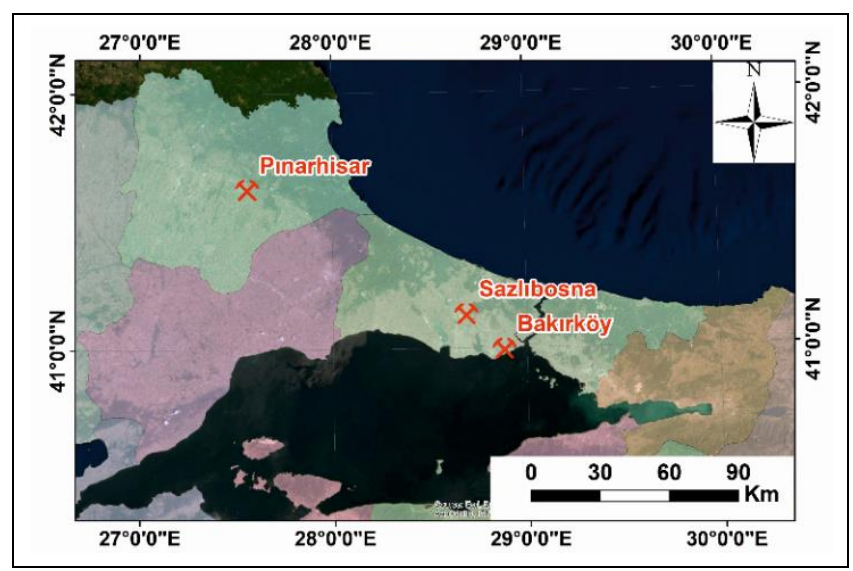

Figure 1. Location map of sampling sites.

Block samples were than saw cut to various dimensions for different tests (e.g. $7 \times 7 \times 7 \mathrm{~cm}$ (freeze-thaw, water absorption), $4 \times 4 \times 4 \mathrm{~cm}$ (salt crystallization), $1 \times 6 \times 12 \mathrm{~cm}$ ( $\mathrm{SO}_{2}$ aging)). Additionally, samples for thin section were also prepared with. representative powder samples that were obtained by milling in agate mortar to obtain samples having grain sizes smaller than $300 \mu \mathrm{m}$ from each sampling points. Powder samples were used in determining specific gravity, loss on ignition, loss in acid and in X-Ray Diffraction analysis.

\subsection{Mineralogical, petrographic and chemical analyses}

Mineralogical studies were conducted to obtain the mineralogical composition of each specimen. X Ray Diffraction (XRD) analysis were utilized during this process on powder samples. A GNR APR 2000 PRO X-ray diffractometer was used under $\mathrm{CuK} \alpha$ radiation with a voltage of $40 \mathrm{kV}$ and a current of $30 \mathrm{~mA}$. The data were collected between $5^{\circ}$ and $55^{\circ}$ for $2 \theta$ values. The petrographic properties defined by the relative existence of mineral grains and matrix of the studied rocks were obtained by thin section analyses under the polarized petrography microscope.

Loss on ignition (LOI) tests were carried out again on powder samples by heating these samples for two hours up to $105^{\circ} \mathrm{C}$ and then heating up to $1050^{\circ} \mathrm{C}$ for three hours. The weight loss between these two heating temperatures was calculated as loss on ignition according to [9].

The last chemical analyses conducted on Küfeki stones was loss in acid (LIA). The powder samples were mixed with $10 \% \mathrm{HCl}$ acid and the weight loss before and after mixing with the acid was reported as loss in acid.

\subsection{Physical and Mechanical tests}

Physical properties such as, unit weight, specific gravity, effective porosity, water absorption, water absorption coefficient by capillarity, P-wave velocity and uniaxial compressive strength tests were carried according to the suggested standard test methods given by [10]-[14].

\subsection{Artificial aging tests}

These test were carried on fresh samples obtained from quarries given in Figure 1. Sodium sulfate crystallization (Resistance against salt crystal) test was conducted according to proposed methods in [15]. Freeze - Thaw effect was conducted as proposed in [9],[16] and sulfur dioxide dry deposition ( $\mathrm{SO}_{2}$ aging) test was accomplished as suggested in [17].

\section{$2.4 \quad$ Cleaning techniques}

Laser cleaning and pressurized micro-sand blasting cleaning techniques were selected to clean the artificially aged stone samples. Laser cleaning was conducted by a device of Quanta Systems and micro-sand blasting was accomplished under a pressure of $0.8 \mathrm{bar}$.

\section{Mineralogical and petrographic properties of Küfeki Stones}

Mineralogical and petrographic studies on Küfeki Stones reveal that even mineralogical properties are similar (Figure 2) due to the variations in petrographic parameters each rock group exhibits unique properties. Bakırköy küfeki stone (BK) is a biomicritic limestone composed of abundant amount of Mactra fossils and fossil fragments. BK also comprises low amount of clay and quartz grains. Vize-Pınarhisar küfeki stone $(\mathrm{P})$ and Sazlıbosna küfeki stone (BH) belong to the same geological formation and exhibit similar lithological properties. Both rocks compose varying amount of clay minerals and many fossils and fossil fragments with quartz grains (Figure 3). Based on XRD analysis, these rocks composed of mainly calcite $(96.9 \%$ for $\mathrm{BK}, 93.3 \%$ for $\mathrm{BH}$ and $85.7 \%$ for P) and lesser amount of quartz and clay (Ca-smectite) minerals $(3.0 \%$ for $\mathrm{BK}, 6.7 \%$ for $\mathrm{BH}$ and $14.3 \%$ for $\mathrm{P}$ ).

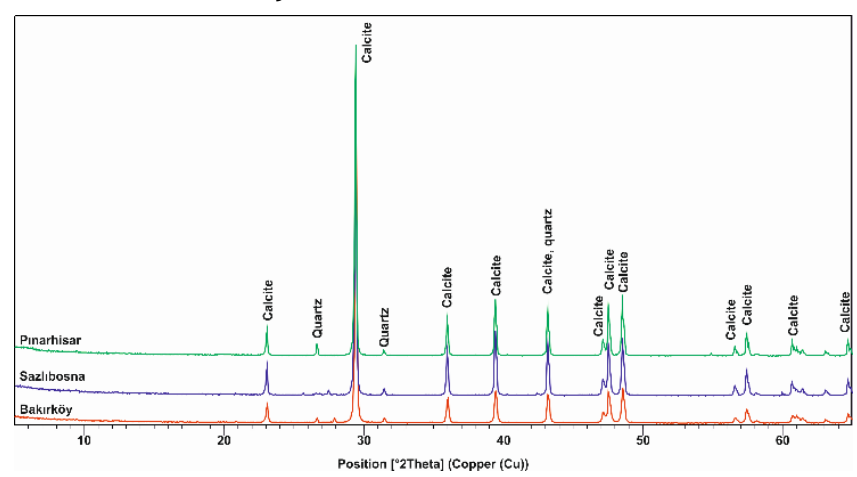

Figure 2. XRD Patterns of the studied stones.

\section{Physical and mechanical properties}

Slight variations in micro-textural properties of the studied rocks generate changes in the physical and mechanical properties. Bakırköy küfeki stone has the highest organic 
material content whereas Pınarhisar küfeki stone exhibits the lowest values. Similarly, the highest LOI values were obtained from Pinarhisar samples. The lowest values for LOI were obtained from Sazlibosna stones. Contrary, LIA values were the highest for Sazlıbosna and lowest for Pınarhisar stones (Table 1).

The specific gravity values for all rock types stand in a narrow range. The water absorption values by weight and volume are in good agreement with the effective porosity values. The porosities of Pınarhisar and Sazlıbosna stones are very close to each other while Bakırköy stone has the lowest effective porosity values (Table 2). The samples with higher porosities absorbed more water both in atmospheric conditions and in boiled water. The highest water absorption values were observed in Pinarhisar stones and the lowest values were obtained by Bakırköy stones. The water absorption coefficient by capillarity values for the studied stones defined according to the suggested methods by [8] are given in Table 3.

The change of capillary water absorption by time graph proposed by the same suggested method is given in Figure 3. According to the data obtained from these tests suggest that Bakırköy stones has the lowest capillary water absorption and Pınarhisar and Sazlıbosna stones have higher capillary water absorption values (Figure 3). Similar values were obtained for the water absorption coefficient by capillarity (Table 3). The water absorption values and effective porosity values given above are in a good agreement. The uniaxial compressive strength of studied stones exhibits similar values. It is also evident that the $\mathrm{P}$ wave values for the studied rocks are low for rocks having high capillary water absorption values and relatively high water absorption coefficient by capillarity (Table 4).

Table 1. Basic petrographic and chemical properties of Küfeki stones.

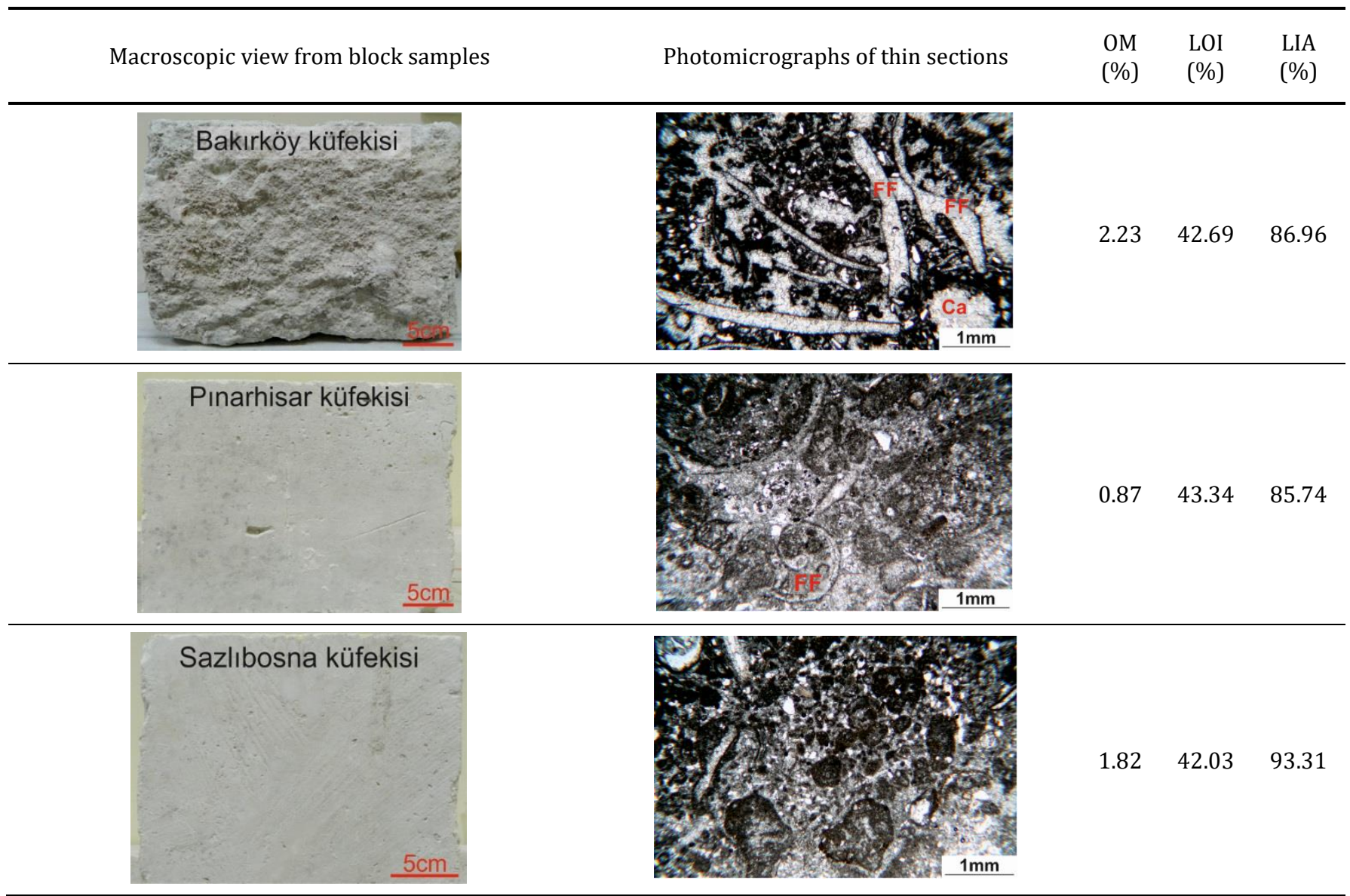

OM: Organic material, LOI: Loss on ignition, LiA: Loss in acid solution, FF: Fossil fragment, Ca: Calcite.

Table 2. Physical properties of Küfeki stones.

\begin{tabular}{ccccccccc}
\hline Sample name & Gs & $\gamma \mathrm{s}\left(\mathrm{gr} / \mathrm{cm}^{3}\right)$ & $\gamma \mathrm{d}\left(\mathrm{gr} / \mathrm{cm}^{3}\right)$ & $\begin{array}{c}\mathrm{Wa}_{(\mathrm{w})} \\
(\%)\end{array}$ & $\begin{array}{c}\mathrm{Wa}_{(\mathrm{v})} \\
(\%)\end{array}$ & $\begin{array}{c}\mathrm{Wa}_{(\mathrm{wb})} \\
(\%)\end{array}$ & $\begin{array}{c}\mathrm{Wa}_{(\mathrm{vb})} \\
(\%)\end{array}$ & $\begin{array}{c}\mathrm{n}_{\text {eff }} \\
(\%)\end{array}$ \\
\hline Bakırköy(BK) & (5) 2.54 & 2.35 & 2.27 & 3.53 & 8.02 & 4.44 & 10.17 & 8.03 \\
Sazlıbosna(BH) & (5) 2.59 & 2.29 & 2.14 & 7.36 & 15.73 & 7.27 & 15.57 & 15.74 \\
Pinarhisar(P) & (5) 2.55 & 2.28 & 2.11 & 7.67 & 16.18 & 8.08 & 17.10 & 16.19 \\
\hline
\end{tabular}

Values in parenthesis shows the sample numbers. Gs= specific gravity, $\gamma \mathrm{s}=$ Saturated unit weight, $\gamma \mathrm{d}=\mathrm{dry}$ unit weight, Wa(w) $:$ water absorption by weight, Wa(wb) $:$ water absorption by weight in boiled water, $\mathrm{Wa}_{(\mathrm{v})}$ : water absorption by volume, $\mathrm{Wa}_{(\mathrm{vb})}$ : water absorption by volume in boiled water, $\mathrm{n}_{\text {eff: }}$ effective porosity. 
Table 3. Water absorption coefficient by capillarity by time for the studied stones.

\begin{tabular}{ccccc}
\hline \multicolumn{5}{c}{ Water absorption coefficient by capillarity $\left(\mathrm{g} / \mathrm{m}^{2 *} \mathrm{~s}^{0,5}\right.$ ) } \\
\hline $\begin{array}{c}\mathrm{t} \\
\text { (minute) }\end{array}$ & $\begin{array}{c}\text { Number of } \\
\text { samples }\end{array}$ & $\mathrm{BK}$ & $\mathrm{BH}$ & $\mathrm{P}$ \\
1 & 6 & 109.16 & 160.67 & 256.66 \\
3 & 6 & 82.14 & 135.55 & 195.84 \\
5 & 6 & 73.70 & 131.02 & 182.19 \\
10 & 6 & 59.59 & 111.99 & 152.39 \\
15 & 6 & 59.69 & 113.80 & 155.51 \\
30 & 6 & 53.77 & 109.64 & 147.17 \\
60 & 6 & 45.09 & 92.57 & 129.45 \\
480 & 6 & 24.12 & 66.49 & 71.21 \\
1440 & 6 & 14.17 & 38.47 & 41.33 \\
\hline
\end{tabular}

g: Gram, $\mathrm{m}^{2}$ : area, $\mathrm{s}^{0.5}$ : Square root of time in seconds.

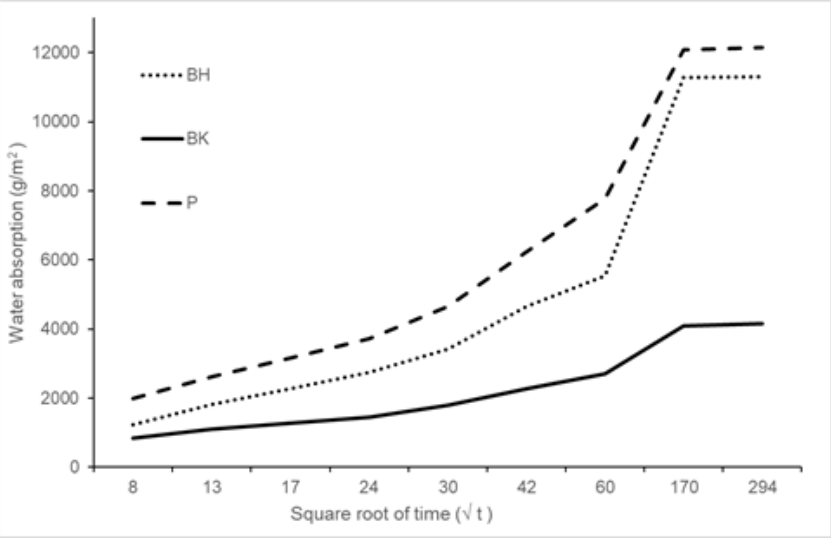

md: mass of dry sample, mi: mass of water absorbed sample, A: area of submerged face of the sample (in $\mathrm{m}^{2}$ ). BK: Bakırköy küfeki stone, BH: Sazlıbosna küfeki stone P: Pınarhisar küfeki stone.

Figure 3. Change of capillary water absorption by time (modified from [18]).

Table 4. Mechanical properties and P-wave velocities of studied rocks.

\begin{tabular}{ccc}
\hline Sample name & UCS (MPa) & Vp (km/s) \\
\hline Bakırköy (BK) & $24(10)$ & $5.06(10)$ \\
Sazlıbosna (BH) & $21(10)$ & $4.47(10)$ \\
Pınarhisar (P) & $19(10)$ & $3.98(10)$ \\
\hline
\end{tabular}

Values in parenthesis shows the number of test samples. UCS: Uniaxial compressive strength, $\mathrm{Vp}$ : P-wave velocity.

\section{Artificial aging tests}

The investigated stones were subjected to freeze-thaw cycles, sodium sulfate crystallization and sulfur dioxide dry deposition $\left(\mathrm{SO}_{2}\right.$ aging) by means of accelerated aging tests to generate polluted stone surfaces. After these tests the weight loss for each sample was measured and results are given in Table 5. The visual changes on the stone surface are provide in Figure 4, 5 and 6. Bakırköy Küfeki stone preserved its initial durability after each accelerated aging test. On the other hand, Pınarhisar and Sazlibosna stones were disintegrated after sodium sulfate crystallization test. Thus no further studies were able to conduct on the samples.

The weight losses after accelerated aging tests for each tested rock group are consistent with the water absorption coefficient by capillarity and capillary water absorption values. The samples with higher weight losses also have higher water absorption coefficient by capillarity.

Table 5. Weight loss in samples after accelerated aging tests.

\begin{tabular}{cccc}
$\begin{array}{c}\text { Sample } \\
\text { name }\end{array}$ & $\begin{array}{c}\text { Weight loss } \\
\text { after salt } \\
\text { crystallization } \\
(\%)\end{array}$ & $\begin{array}{c}\text { Weight loss } \\
\text { after freeze- } \\
\text { thaw cycles } \\
(\%)\end{array}$ & $\begin{array}{c}\text { Weight loss } \\
\text { after sulfur } \\
\text { dioxide dry } \\
\text { deposition } \\
\left(\mathrm{SO}_{2} \text { aging) }\right. \\
(\%)\end{array}$ \\
\hline Bakırköy & 4.15 & 0.106 & 0.11 \\
Sazlıbosna & $\begin{array}{c}\text { Disintegrated } \\
\text { Pinarhisar }\end{array}$ & 0.178 & 0.14 \\
\hline
\end{tabular}

Six measurements were carried out on every sample for each test and the average value are given.

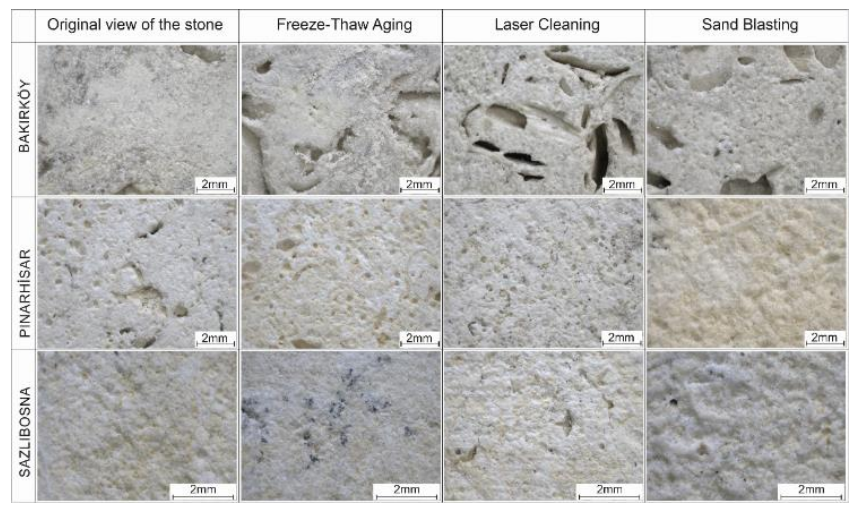

Figure 4. Macroscopic view of stone samples after which are aged by freeze-thaw cycles and cleaned with different cleaning techniques (modified from [18]).
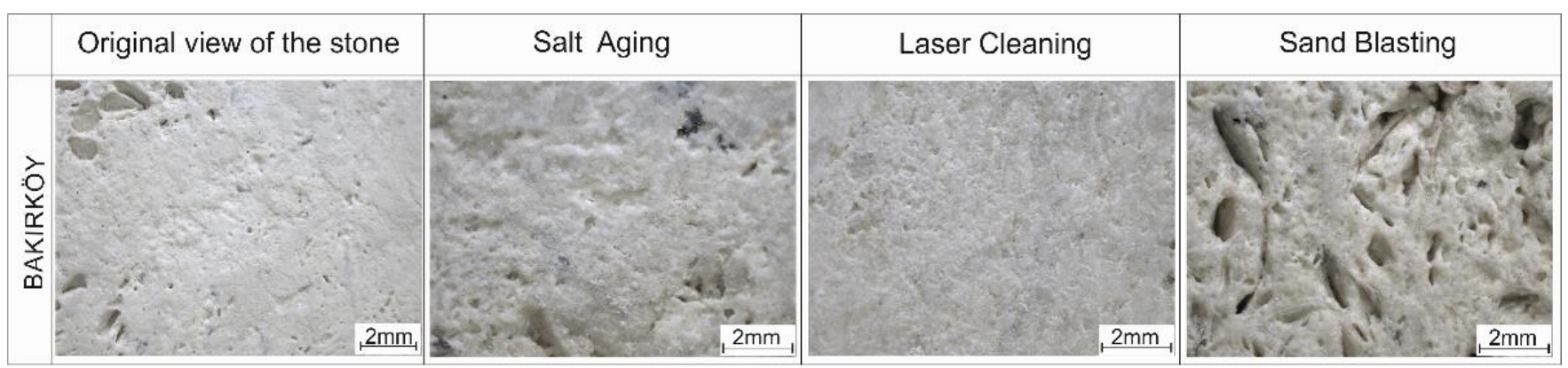

Figure 5. Macroscopic view of samples after which are aged by sodium sulfate crystallization and cleaned with different cleaning techniques (modified from [18]). 


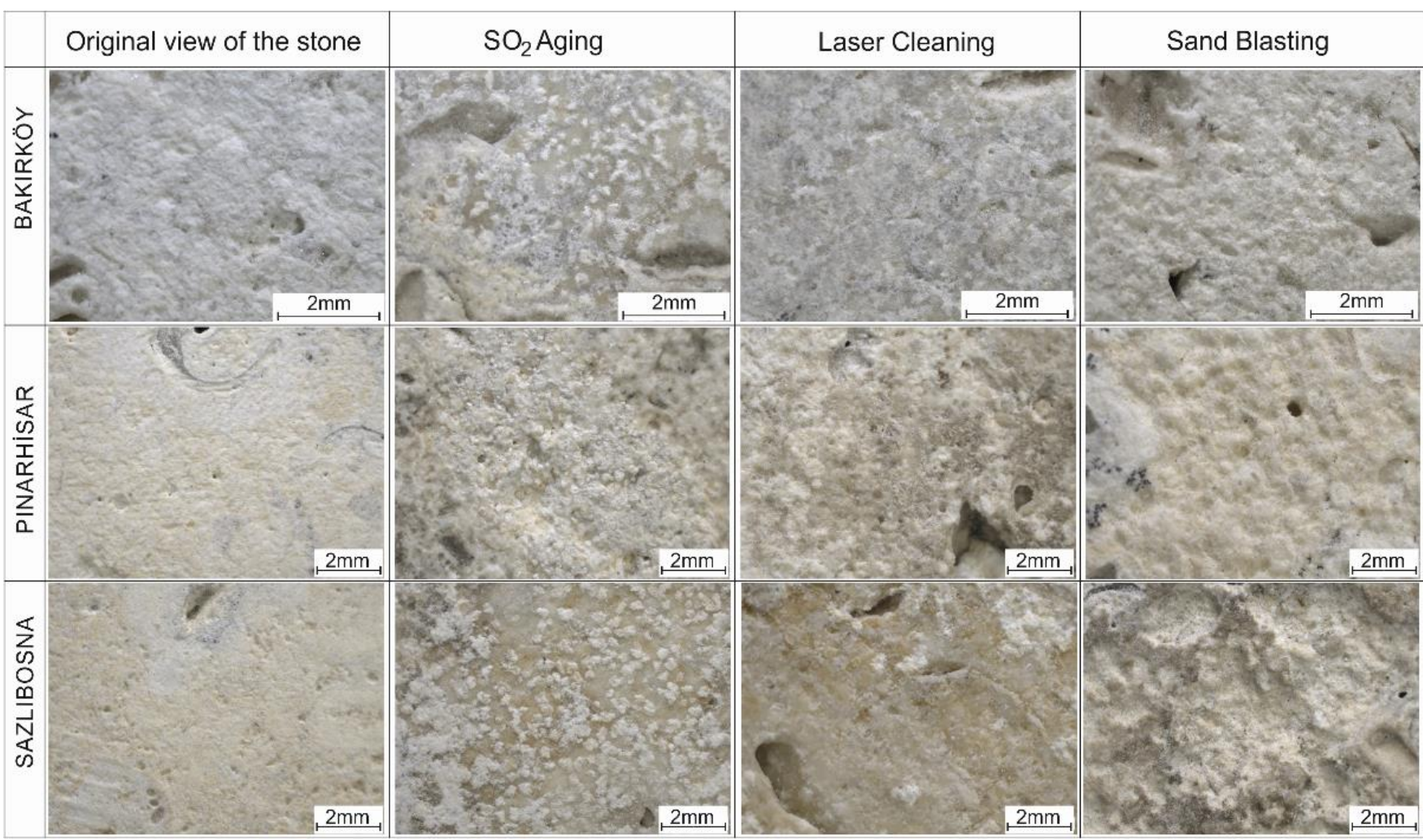

Figure 6. Macroscopic view of stone samples after which are aged by sulfur dioxide dry deposition and cleaned with different cleaning techniques (modified from [18]).

\section{Changes on the cleaned stones}

The polluted stone surfaces by accelerated aging tests (freezethaw cycles, salt crystallization and sulfur dioxide dry deposition ( $\mathrm{SO}_{2}$ aging) ) were cleaned by laser and pressurized micro-sand blasting cleaning techniques. The weight losses of stones after using two different cleaning techniques on varying pollutant effects for each group are given in Table 6 and 7 separately. The visual changes after the cleaning procedure are given in Figures 4, 5 and 6 for different rock types and cleaning technique.

Laser cleaning techniques caused lesser weight loss than pressurized micro-sand blasting on all of the three types of stones which were polluted by freeze-thaw cycles (Table 6 and 7). After the accelerated test conducted by sodium sulfate crystallization only Bakırköy stone preserved its structure. Pınarhisar and Sazlıbosna stones were disintegrated to gravel size that prohibit the application of a cleaning procedure. The laser cleaning technique also end up with lower weight loss than pressurized micro-sand blasting for this accelerated aging test on Bakırköy stone. Similarly, weight losses due to laser cleaning on the rock samples aged by sulfur dioxide dry deposition ( $\mathrm{SO}_{2}$ aging) were lower than the weight losses obtained by micro-sand blasting cleaning (Table 6 and 7). But a thin gel and a crust layer were formed on the stone surfaces during the sulfur dioxide dry deposition $\left(\mathrm{SO}_{2}\right.$ aging $)$ accelerated aging method. The crust layer was removed by the laser technique but the gel formed during the sulfur dioxide dry deposition ( $\mathrm{SO}_{2}$ aging) accelerated pollution method was remained. Pressurized micro-sand blasting method was able to remove both the gel and crust layer. For this reason, a thicker change was generated on the stone surfaces which is an evident for the higher weight losses. Besides, more roughness was generated on the stone surfaces due to micro-sand blasting technique than the laser cleaning technique.

Table 6. Weight losses after laser cleaning techniques.

\begin{tabular}{cccc}
\hline $\begin{array}{c}\text { Sample } \\
\text { name }\end{array}$ & $\begin{array}{c}\text { Freeze- } \\
\text { Thaw (\%) }\end{array}$ & $\begin{array}{c}\text { Salt } \\
\text { crystallization } \\
(\%)\end{array}$ & $\begin{array}{c}\mathrm{SO}_{2} \text { vapor } \\
(\%)\end{array}$ \\
\hline Bakırköy & 0.16 & 0.115 & 0.01 \\
Pinarhisar & 0.09 & - & 0.11 \\
Sazlıbosna & 0.13 & - & 0.13 \\
\hline
\end{tabular}

Table 7. Weight losses after micro-sand blasting techniques.

\begin{tabular}{cccc}
\hline $\begin{array}{c}\text { Sample } \\
\text { name }\end{array}$ & $\begin{array}{c}\text { Freeze- } \\
\text { Thaw (\%) }\end{array}$ & $\begin{array}{c}\text { Salt } \\
\text { crystallization } \\
(\%)\end{array}$ & $\begin{array}{c}\mathrm{SO}_{2} \text { vapor } \\
(\%)\end{array}$ \\
Bakırköy & 0.22 & 0.25 & 0.52 \\
Pinarhisar & 0.26 & - & 1.12 \\
Sazlıbosna & 0.37 & - & 1.24 \\
\hline
\end{tabular}

\section{Conclusions}

The evaluation of weight loss and visual appearances of various rocks types after accelerated aging tests and cleaning procedures are given below.

Micro-sand blasting technique generates new rough surfaces which can be seen by naked eyes on the surfaces of cleaned stones.

It is important to detect the main polluting agent, at least at a basic level, before choosing and applying appropriate cleaning technique. 
The effect of petrographic and physical properties of the stone should be considered in defining the appropriate cleaning technique

It is strongly concluded that the water absorption coefficient by capillarity of küfeki stones influences the pollution process and the efficiency of cleaning method. It is evident that the stones with lower water absorption coefficient by capillarity and lower capillary water absorption values are more resistance to pollution effects and less damages generated during cleaning procedure.

The study concludes that during cleaning or restoration of studied stones, it is also essential to define the usage type of the stones. According to this, stones used as load-bearing function should be cleaned by laser cleaning system which has lower effect on the weight loss. On the other hand, stones which are not used in load-bearing systems and are more important by visual appearances can be cleaned by micro-sand blasting technique that wipes away the entire polluted crust and bring new surface to light.

\section{References}

[1] Angı OS, Yavuz O, Çiftçi E. "Geo-lithological and architectonical properties of indigenous building and ornamental stones used in landmark structures in istanbul from past to present". Istanbul Yerbilimleri Dergisi, 28(1), 163-196, 2015. (in Turkish).

[2] Arıç C. The Eology of Haliç-Küçükçekmece Region. PhD Thesis, İstanbul Teknik Üniversitesi, İstanbul, Türkiye, 1955. (in Turkish).

[3] Mahmutoğlu Y, Angı OS, Özmen IE, Yeșilkaya Z. "Investigation of potential resource areas of indigenous natural stones used in historical buildings in Istanbul". National Engineering Geology and Geotechnic Symposium, Denizli, Türkiye 12-14 Ekim 2017. (in Turkish).

[4] Kumral M, Şans G, Yalçın C, Kaya M, Bodakoğlu M. "The effects of physical and chemical properties on the formation of historical küfeki stone in Çatalca (Istanbul)". Ömer Halisdemir Üniversitesi Mühendislik Bilimleri Dergisi, 8(1), 278-287, 2019. (in Turkish).

[5] Serhatoğlu C. Livaoğlu R. "A fast and practical approximations for fundamental period of historical Ottoman minarets". Soil Dynamics and Earthquake Engineering, 120, 320-331, 2019.
[6] Tuğrul A, Zarif H, Yıldırım M, Gürpınar O. "Effective factors in deterioration of limestones used in historical buildings and monuments in İstanbul". İstanbul Üniversitesi Mühendislik Fakültesi Yerbilimleri Dergisi, 12, 39-51, 1999. (in Turkish).

[7] Spry AH. Principles of Cleaning Masonry Buildings. Melbourne, Australia, Australian Council of National Trusts, 1982.

[8] Sayar M, Erguvanlı K. Marbles and Construction Stones of Turkey. İstanbul, Türkiye, İTÜ Yayınları, 1962. (in Turkish).

[9] Türk Standartları. "Natural Building Stones-Experimental Methods". Ankara, Türkiye, 699, 1988.

[10] International Society for Rock Mechanics (ISRM). "The complete ISRM suggested methods for rock characterization, testing and monitoring". Kozan, Ankara, Türkiye, 2007.

[11] International Society for RockMechanics (ISRM). "In: Brown ET. (Ed.), Rock Characterization Testing and Monitoring- ISRM Suggested Methods". New York, USA, 1981.

[12] Türk Standartları. "Natural Stones Experimental MethodsDetermination of the Coefficient of Water absorption Coefficient by capillarity". Ankara, Türkiye, EN 1925, 2000.

[13] Türk Standartları. "Natural Stones Experimental MethodsDetermination of Compressive Strength". Ankara, Türkiye, EN 1926, 2000

[14] Türk Standartları. "Natural Stones Experimental MethodsDetermination of Sonic Wave velocity". Ankara, Türkiye, EN 14579, 2006.

[15] Türk Standartları. "Natural Stones Experimental MethodsDetermination of Salt Crystallization". Ankara, Türkiye, EN 12370, 2001.

[16] Türk Standartları. "Natural Stones Experimental MethodsDurability Against Freeze-Thaw cycles". Ankara, Türkiye, EN 12371, 2003.

[17] Türk Standartları. "Natural Stones Experimental Methods-Determination of Rock Strength Against SO2 Aging". Ankara, Türkiye, EN 13919, 2004.

[18] Erözmen T. Lithological properties of Küfeki Rocks Used in Historical Monuments and Their Behaviours Against Cleaning Techniques. Yüksek Lisans Tezi, İstanbul University-Cerrahpaşa, İstanbul, Türkiye, 2019. (in Turkish). 